\title{
Surplus Food Recovery and Food Aid: The Pivotal Role of Non-profit Organisations. Insights From Italy and Germany
}

\author{
Simone Baglioni ${ }^{1}$ (D) Benedetta De Pieri $^{1}$. \\ Tatiana Tallarico ${ }^{2}$
}

Published online: 22 June 2016

(C) The Author(s) 2016. This article is published with open access at Springerlink.com

\begin{abstract}
Food security and food waste are unanimously recognised as relevant issues affecting the whole society and should be therefore acknowledged as a priority on the public agenda. Nonetheless, in many countries the third sector stands in for public actors and operates to tackle both these issues. This paper explores the role of public and third sector in tackling food poverty and food waste, particularly analysing the role of the non-profit organisations involved in the food recovery and redistribution processes in two European regions: Lombardy (Italy) and BadenWürttemberg (Germany). By comparing the two different policy framework and the organisations' actions, the study recognises the ability of the non-profit sector to create new relationships among different actors (private for-profit, private non-profit as well as public actors) while answering various unmet needs. The paper draws on a mix of secondary and primary data including observations and interviews in the two regions carried out in 2014 and focuses on two relevant case studies (the "Associazione Banco Alimentare" and the "Tafel").
\end{abstract}

Résumé La sécurité et les résidus alimentaires sont unanimement reconnus comme des enjeux importants pour la société en général. Ils devraient conséquemment se situer au premier rang des préoccupations des programmes publics. Dans plusieurs pays, c'est pourtant les intervenants du tiers secteur qui jouent le rôle d'acteurs sur

Simone Baglioni

simone.baglioni@gcu.ac.uk

Benedetta De Pieri

benedetta.depieri@gcu.ac.uk

Tatiana Tallarico

tatiana.tallarico20@gmail.com

1 Yunus Centre for Social Business and Health, Glasgow Caledonian University, Glasgow, UK

2 Cergas, Bocconi University, Milan, Italy 
la scène publique et agissent pour surmonter ces enjeux. Cet article explore le rôle que jouent les secteurs public et tiers pour lutter contre la pauvreté et les pertes alimentaires, particulièrement en analysant celui des organismes sans but lucratif impliqués dans les processus de prise en charge et de redistribution d'aliments dans les deux régions européennes suivantes : Lombardie (Italie) et Bade-Wurtemberg (Allemagne). En comparant deux cadres de travail politiques différents et les gestes des organismes, l'étude reconnaît la capacité du secteur sans but lucratif à tisser de nouveaux liens entre divers acteurs (privés à but lucratif, privés sans but lucratif et publics), tout en satisfaisant plusieurs besoins inassouvis. L'article utilise un amalgame de données secondaires et primaires, dont des observations et des entretiens réalisées dans les deux régions en 2014, et se concentre sur deux études de cas pertinentes (la « Associazione Banco Alimentare » et la « Tafel »).

Zusammenfassung Ernährungssicherheit und Nahrungsmittelverschwendung werden einstimmig als für die gesamte Gesellschaft relevante Themen anerkannt und sollten daher als eine Priorität auf der öffentlichen Agenda behandelt werden. Nichtsdestotrotz tritt in vielen Ländern der Dritte Sektor an die Stelle öffentlicher Akteure und arbeitet daran, diese beiden Probleme zu lösen. Der Beitrag untersucht die Rolle des öffentlichen und Dritten Sektors bei der Bekämpfung der Ernährungsarmut und Nahrungsmittelverschwendung und analysiert insbesondere die Rolle gemeinnütziger Organisationen, die in den Prozessen zur Wiederherstellung der Ernährungssicherheit und -umverteilung in zwei europäischen Regionen involviert sind: in der Lombardei in Italien und im deutschen Baden-Württemberg. Anhand eines Vergleichs zwischen den beiden unterschiedlichen politischen Rahmenbedingungen und den Handlungen der Organisationen erkennt die Studie die Fähigkeit des gemeinnützigen Sektors, neue Beziehungen zwischen verschiedenen Akteuren (private gewinnorientierte, private gemeinnützige und öffentliche Akteure) aufzubauen und diverse unbefriedigte Bedürfnisse zu erfüllen. Bei der Abhandlung stützt man sich auf eine Kombination aus sekundären und primären Daten, einschließlich Beobachtungen und Interviews, die 2014 in den beiden Regionen durchgeführt wurden, und konzentriert sich auf zwei relevante Fallstudien (die „Associazione Banco Alimentare“und die „Tafel“).

Resumen Se reconoce de manera unánime que la seguridad alimentaria y los residuos alimentarios son problemas relevantes que afectan a toda la sociedad y, por consiguiente, deben ser reconocidos como una prioridad en la agenda pública. No obstante, en muchos países, el sector terciario sustituye a los actores públicos y opera para afrontar ambos problemas. El presente documento explora el papel del sector público y del sector terciario afrontando la pobreza alimentaria y los residuos alimentarios, en particular analizando el papel de las organizaciones sin ánimo de lucro implicadas en los procesos de recuperación y redistribución de alimentos en dos regiones europeas: Lombardía (Italia) y Baden-Württemberg (Alemania). Al comparar los dos marcos políticos diferentes y las acciones de las organizaciones, el estudio reconoce la capacidad del sector sin ánimo de lucro para crear nuevas relaciones entre diferentes actores (organizaciones privadas con ánimo de lucro, organizaciones privadas sin ánimo de lucro, así como también actores públicos) 
respondiendo al mismo tiempo a las diversas necesidades no satisfechas. El documento recurre a un mix de datos primarios y secundarios, incluyendo observaciones y entrevistas en las dos regiones llevadas a cabo en 2014, y se centra en dos estudios de casos relevantes (la "Associazione Banco Alimentare" y la "Tafel”).

Keywords Food aid · Non-profit organisations · Social innovation

\section{Introduction}

The notion that non-profit organisations are a consistent part of the European welfare state is not a disputed issue. Even in the so-called generous welfare regimes such as Nordic European countries, where public action has been predominant in welfare service delivery and funding, non-profit organisations have started to play an increasingly relevant role (Pestoff 2009; Defourny et al. 2014). Furthermore, non-profit action has been even more prominent in a sector like food poverty, in which most welfare state regimes have almost completely devolved their capacity and responsibility to societal actors.

The lack of public actors' intervention in this sector can be attributed to various factors. First, European or-more generally, affluent-societies consider their populations sheltered from the risk of undernourishment and social strata with fewer resources are not at food security risk given the support made available through general welfare provisions. Therefore, the public welfare action that has taken place in relation to food has been driven by the need to reduce food consumption and address health issues related to over-eating (obesity has become a key issue in health care across affluent societies).

Second, in all European countries, there is a tradition of charities taking care of the delivery of basic goods (foods, clothing, medicines) either in case of emergency or as a support to particularly vulnerable groups, such as asylum seekers, homeless people or those with drug and alcohol addictions (Zimmer and Evers 2010). Thus, public action in the field of food poverty has mainly limited its role to allowing such civil society-driven actions to continue.

Public actors have only started considering more consistently the need for policies addressing food poverty more recently, when the economic globalisationalong with the 2008 economic and financial crisis-led to the impoverishment of working and even middle classes. Pressed by the potentially deeply detrimental effect of the increasing polarisation between affluent and deprived people on social cohesion, governments in European countries have started addressing the topic of food poverty, supporting the existing non-profit initiatives as well as focusing on two areas: promoting awareness campaigns to reduce edible food waste and putting in place fiscal incentives to ease surplus food recovery and corporate food donations. Nevertheless, in most countries, non-profit actors are the principal service and policy providers in the field of food redistribution to the needy.

In this paper, we argue that non-profit action related to food povertyparticularly food recovery and redistribution-has led to social innovation filling the gap determined by the lack of public intervention. Non-profit organisations have 
developed new ways of addressing the unmet material and non-material needs of various actors such as people experiencing poverty, food companies producing surplus food and public institutions facing economic crisis.

Some critical views of non-profit action in this field highlight the risk of these organisations cementing exclusion rather than tackling it (Lorenz 2012; Selke 2009; Riches 2011). By contrast, we argue that if combined with wider interventions to tackle marginalisation, the action of food recovery organisations fulfils a socially relevant function by answering an urgent need for food as well as avoiding waste along the food supply chain. We show that these actions take place in a context of very limited public intervention and where existing public policies tend to obstruct rather than enable organisations' work.

The paper is based upon research investigating food recovery and redistribution practices in two European regions: Lombardy in Italy and Baden-Württemberg in Germany. The research design uses the most-similar comparative case model. These two regions share a similar profile of strong economic development and industrialisation (both are among the wealthiest areas in Europe) and both have been pioneering in starting organised practices of food recovery to tackle food poverty in their respective countries. Moreover, Germany and Italy have similar occupational and continental welfare systems, in which civil society has long played a strong complementary role alongside state provision (Zimmer and Brauer 2015). Given the exploratory nature of our study, we have opted for a qualitative approach based upon case studies (Yin 1989; Denzin and Lincoln 2000) allowing us an in-depth understanding of specific non-profit actions in given contexts. We interviewed eleven non-profit entities in Lombardy and five in Baden-Württemberg using semi-structured questionnaires. Interviews were usually conducted with more than one person for each organisation, and during observations we also had the opportunity to speak with the volunteers. Each interview was recorded and transcribed, with transcriptions checked by at least two researchers. Transcriptions and field notes were analysed both individually as well manually by each of the authors, while the final analysis presented here is the result of crossed reading of the authors' analyses and related discussions. ${ }^{1}$

The paper first introduces the theme of food poverty and surplus food generation as a global issue, before briefly presenting the role undertaken by public actors. It subsequently presents the policy contexts in which non-profit organisations operate in Germany and Italy. The final section discusses the research findings concerning the role of non-profit organisations in food recovery and redistribution in the two local contexts. Finally, some concluding remarks are outlined.

\section{The Problem of Food Poverty and Edible Food Waste in High-Income Countries}

According to the FAO, "food security exists when all people at all times have physical, social and economic access to sufficient, safe and nutritious food to meet dietary needs and food preferences for an active and healthy life" (FAO 2009, p. 8).

\footnotetext{
1 More information about the project and the research methods and tools can be found on the project's website: http://www.foodsavingproject.it.
} 
Despite good progress made in the early-1990s to reduce chronic hunger, the number of undernourished people in the world has been slowly increasing for a decade, rising above 800 million. This has not only occurred in low-income countries but also in high-income ones, owing to the current economic crisis (IFRC 2013).

However, in high-income countries "food poverty" has always received less attention than "poverty" in general (Friel and Conlon 2004). The link between food access and social exclusion remained unacknowledged until recently, when it was recognised as a growing issue requiring appropriate social policies and welfare intervention (Dowler 1998). At the same time, a growing number of scholars have started studying it (Conceição and Mendoza 2009; Duffy et al. 2002; EnglerStringer and Berenbaum 2007; Gregory et al. 2005; Jha 2009; Lang and Barling 2012; Riches 2002). In particular, the contradiction between food poverty affecting a large section of the global population and the everyday wastage of food has become a relevant topic in both academic and public debates. The FAO has pointed out that despite millions of people suffering hunger, "roughly one-third of the edible parts of food produced for human consumption gets lost or wasted globally, which is about 1.3 billion tonne per year" (FAO 2011, p.4).

Following Garrone et al. (2014b), we refer here to "surplus food" as edible and "safe food that for various reasons, at any stage of supply chain, is not sold to or consumed by the intended customer" (Garrone 2014b, p. 1461). Surplus food generation occurs at different stages of the food production chain. In low-income countries, it is concentrated at post-harvest and processing levels due to inefficiencies, climate conditions and other limits. In high-income countries, it mainly occurs at the retail and consumer levels, as a result of marketing strategies, product and packaging deterioration or errors in forecasting demand (BCFN 2012; Garrone et al. 2014a).

The waste of surplus food has several impacts, including increasing water consumption, depleting environmental resource use and generating carbon dioxide equivalent emissions. It also affects the economy, as food has a commercial value and-most importantly-it has significant social consequences, contributing to the strong contradiction with the worldwide spread of food poverty (BCFN 2012; FAO 2011; Ferrara and Missions 2012; Finn 2011; Garrone et al. 2014a, b; Parfitt et al. 2010; Schneider 2012; Schneider and Lebersorger 2012).

Although the reduction of surplus food generation is both a political tool to tackle food poverty and an economic urgency for food companies interested in increasing their efficiency and optimising their processes, a given amount of surplus food is unavoidable (Garrone et al. 2014b). Therefore, its redistribution to the most deprived can be considered as a valuable alternative to waste (FAO 2011; BCFN 2012). For instance, the Barilla Centre for Food and Nutrition recognises that "launching initiatives to recover waste through distribution to disadvantaged persons" is one of the global political priorities (BCFN 2012).

We are aware that surplus food redistribution cannot be the only way to tackle food poverty in high-income countries. Instead, considering the complexity of food systems (Lang and Barling 2012), it should be combined with other interventions such as social protection mechanisms and safety nets for the most vulnerable; 
otherwise, the risk that surplus food redistribution contributes more to cement marginalisation rather than overcoming it becomes increasingly realistic. In fact, the presence of organisations distributing surplus food can involuntarily provide a favourable excuse for policy-makers to postpone wider interventions (Selke 2009), given that such organisations manage to alleviate the urgency of food poverty.

\section{The Role of Public Actors in Surplus Food Recovery}

Although surplus food recovery is recognised by many as a political priority (Parfitt et al. 2010; Bloom 2010 as in Eng 2011; Finn 2011; FAO 2011; BCFN 2012; Deloitte 2014), de facto very little is done in terms of public policies, while civil society and bottom-up initiatives are intervening in this field in many European countries.

Concerning the role of public initiatives, a study at the European level by Bio by Deloitte identifies four main relevant policy areas to ease surplus food donation and increase redistribution: the definition of a common "food use hierarchy", the use of fiscal incentives for both donating companies and non-profit organisations, the liability legislation and the reform of food durability and 'best before' dates (Deloitte 2014). Some countries have already developed policies in these fields, although there remains a room for improvement.

First, the commitment to a common food use hierarchy prioritising food recovery for human consumption over waste disposal and other uses (e.g. feeding animals or recycling) could be an effective element to improve donations, particularly if balanced with coherent economic incentives (Deloitte 2014). In contrast to the USA, where a "food waste recovery pyramid" was set by the Environmental Protection Agency (BCFN 2012), at the time of this study there is no a common food use hierarchy at the EU level, meaning that the issue is left to the discretion of national governments. Consequently, in the absence of any enforcing regulation and with the exception of a few cases such as Belgium and France, in many European countries it remains more convenient for companies to send surplus food to anaerobic digestion ${ }^{2}$ rather than recovering it (Deloitte 2014).

The second area of policy intervention relates to fiscal incentive instruments such as tax credits. Although the former have proven to be the most effective incentive to encourage food donations against anaerobic digestion, only in a few European countries can companies claim a convenient tax credit. For instance, in France and Spain, donors benefit from a tax credit of respectively 60 and $35 \%$ of the net book value, namely the value of the donated food equal to its original cost minus its depreciation (Deloitte 2014).

Liability issues are another relevant barrier to food surplus donation. In fact, under the EC Regulation n. 178/2002 (the so-called "General Food Law"), food donation is equated to any other market operation, meaning that food donors are

\footnotetext{
2 "Anaerobic digestion is a biological process that occurs when organic matter (in liquid or slurry form) is decomposed by bacteria in the absence of oxygen (i.e., anaerobic)" (United States Environmental Protection Agency-EPA, http://www.epa.gov/agstar).
} 
regarded as general food business operators. Consequently, all the actors involved in the process of food donation, recovery and distribution must comply with the regulation in terms of liability, traceability, food health and safety (Deloitte 2014). Therefore, such liability makes many companies reluctant to donate to avoid the risk of damaging their own reputation after cases of food poisoning or general misuse (Planchenstainer 2012; Deloitte 2014). To overcome companies' reluctance to donate for liability implications, France has recently approved a law that, besides defining a national food use hierarchy, has proclaimed it illegal for large retailersunder certain conditions - not to donate their unsold food products to charities (Law $\mathrm{n}^{\circ}$ 2016-138) ..$^{3}$

A fourth policy topic concerns food durability and food labels. In Europe, there is a general misunderstanding about the meaning of date marking and the possibility of consuming food that has passed its "best before" date, as confirmed by a recent Flash Eurobarometer (2015). Not only is this one of the main causes of household food waste (European Commission 2010), but it also creates barriers to food recovery and redistribution (Deloitte 2014). Among the European countries, only the Federal Agency for the Safety of the Food Chain in Belgium has published guidelines to clarify the interpretation concerning the minimum durability, traceability, labelling and storage of food for national food banks and food charities (Deloitte 2014).

Finally, besides enforcing regulations, governments' pivotal role (Finn 2011) lies in educating communities and changing behaviours over time, by engaging individuals "in supporting the development of new social norms and fostering facilitating conditions in a strategic and long-term approach" (DEFRA 2005, p. 1). Concerning food waste and food recovery, Germany and France are two examples among only a few countries launching educational campaigns at a governmental level, namely "Zu gut für die Tonne" and "Réduisons nos déchets", respectively (BCFN 2012; European Commission 2010; FAO 2011).

To summarise, until recently food recovery as an instrument to mitigate food poverty was marginalised in the political agenda of European countries. Furthermore, most of the enacted policies address private companies as the main actors responsible for food surplus generation and management and-to a lesser extentnon-profit organisations in charge of food distribution.

However, the latter are actually key actors in the donation chain, since they directly manage the collection of surplus food generated by companies and distribute it to those in need. Acting in a space constrained by a lack of systematic policies and the existence of private companies' economic interests, non-profit actors have created their own modes of action that help to meet various needs (individuals' need to access food, companies' need to manage waste and overproduction, governments " need to tackle inequality and poverty) and address environmental issues.

\footnotetext{
${ }_{3}$ https://www.legifrance.gouv.fr/eli/loi/2016/2/11/AGRX1531165L/jo/texte.
} 
In the next section, we present an overview of the key Italian and German legislation and policies concerning the issue of surplus food recovery and donation, before discussing our research findings about non-profit actors working in the recovery and redistribution of surplus food in Lombardy and Baden-Württemberg.

\section{Public Policies in the Field of Food Recovery and Redistribution in Italy and Germany}

\section{Italy}

In Italy, only a few measures exist to support surplus food recovery and donation, although some of them are undermined by bureaucratic boundaries and regulatory contradictions. For example, it is possible for companies to treat food donations as a deductible expense to reduce their taxable income. As specified by Legislative decree of 14 March 2005, n. $35,{ }^{4}$ donations in kind to entities like Onlus (Italian non-profit organisations with a special fiscal status) are fully deductible up to $10 \%$ of their taxable income, albeit with a limit of 70,000 euros per year.

Italy is also one of the few European countries where no VAT is levied on food donations. According to the Legislative decree n.460 of 4 December 1997, food donations to an Onlus are VAT exempted. Moreover, according to the Law 133 of 13th May 1999, unmarketable food products donated to Onlus are considered as "destroyed" in terms of the application of VAT. However, a questionable consequence of this regulation is that a company can donate surplus food to a non-profit organisation or destroy it, receiving the same tax exemption in either case. Companies and non-profit organisations involved in this recovery process argue that this equivalence does not constitute an effective incentive for food donation, as it is often more convenient for companies to send surplus food to landfill or composting (Azzurro 2015).

Nonetheless, in Italy some bureaucratic boundaries hinder the VAT exemption. For example, companies must submit a preliminary declaration to the finance police, indicating the exact quantity and type of donated products for donations exceeding 5164.57 euros. This declaration poses real problems to companies donating surplus food, given that it is often impossible to forecast the exact amount and type of surplus food generated (Azzurro 2015).

However, Italy due to its so-called "Good Samaritan Law" stands out compared to other countries in terms of policies supporting food recovery. The burden of liability on donated products and the dread of misuse by non-profit organisations make many companies reluctant to donate to avoid the risk of damaging their reputation (Planchenstainer 2012; Deloitte 2014). With the Good Samaritan Law, non-profit organisations receiving the donation are regarded as final consumers. This means that companies' liability ends where non-profit organisation begins

\footnotetext{
${ }^{4}$ Decreto legislativo 14 marzo 2005, n. 35 Disposizioni urgenti nell'ambito del Piano di azione per lo sviluppo economico, sociale e territoriale http://www.normattiva.it/uri-res/N2Ls?urn:nir:stato:decreto. legge:2005-03-14;35!vig.
} 
operating. Thus, companies receive an extra level of assurance and-as long as food safety is guaranteed concerning their internal processes-they are not prosecutable in cases of subsequent poisoning or misuse.

Despite the positive influence of the "Good Samaritan Law", several critical issues emerged in a recent consultation exercise aimed at producing a position paper addressed to the Italian Minister of Environment. In particular, the consultation showed that the most critical issues are the lack of a clear and homogeneous legal framework regarding hygiene, safety and standardised procedures, the high-handed bureaucracy burdening both organisations and donating companies and the lack of incentives compensating donors for the expenses that they would face, since the donation itself requires specific financial and human resources (Azzurro 2015). The consultation also concerns the need to introduce homogeneous systems of measurement, accountability and monitoring of donations at the national level, as systems that could also have negative spillover effects on procedures (Azzurro 2015).

\section{Germany}

As in the Italian case, in Germany no VAT has been imposed on food donation since 2012, following a legal dispute between the tax office and a baker who refused to pay tax on the surplus bread that he had been donating. Starting from that court case, the German authorities ruled that donations should be tax exempted, unless a receipt for the donation is issued by the donor (Deloitte 2014).

Instead, it is possible to consider donations - in both kind and cash - as taxdeductible expenses. However, while such a measure is already considered in Italy, the German rules demonstrate a slightly higher willingness to boost food recovery, as the limit for tax deduction is equal to $20 \%$ (compared to a $10 \%$ threshold in Italy) of the corporation's income, or $0.4 \%$ of revenue plus wages and salaries in the relevant year (Deloitte 2014).

To reduce the general flexibility of European legislation in the matter of food security, the German government has arranged to entirely incorporate the General Food Law into national legislation. The Federal Ministry of Food and Agriculture has shown its commitment by issuing a guide explaining the legal issues surrounding food donations, including food hygiene and safety matters (Deloitte 2014). Therefore, Germany is not only eliminating the distance from those countries with more rigid national limits based upon European food legislation, but it has also directly acted in helping stakeholders to deal with the latter's flexibility.

While no evidence is provided regarding the issue of food durability and date marking in Italy, in Germany it is forbidden to donate food that has passed its "use by" date. However, it is permissible to do so with goods having past their "best before" dates, if this is clearly signalled. Moreover, the product may even still be merchandised at the full responsibility of the company. Nonetheless, the misunderstanding between these two labels remains a cause of food waste, not only within domestic homes but also in many groceries. Indeed, this is the reason why efforts are made (e.g. by the German Logistic Association) to clarify the difference between 'best before' and 'use by' dates by raising consumers' awareness that many 
products remain edible even after their "best before" date (BFCN 2012; Deloitte 2014).

An important initiative launched by the Federal Ministry of Food and Agriculture in 2012 is the "Too Good for the Bin" ("Zu Gut für Die Tonne") campaign, aimed at reducing food waste by involving the entire food chain from farm to fork. The campaign particularly addresses consumers, providing them with practical advice concerning how to manage food properly (Federal Ministry of Food, Agriculture and Consumer Protection 2012). The importance of this initiative is that it represents one of the policy options recommended by the European Commission (2010) and one of the three most effective according to an impact assessment evaluation carried out by the Commission itself. In this respect, Germany is one of the few countries implementing such a broad education campaign (BCFN 2012; European Commission 2010; FAO 2011), while Italy had only launched its own at the time of our study (Segré 2014).

Nevertheless, the Federal Government of Germany acts more as a promoter and coordinator of initiatives rather than a provider of welfare services in this sector. In Germany as well as Italy, non-profit actors play a pivotal role in food poverty and food recovery practices.

The next session discusses our research findings, elucidating how non-profit actors work in this field.

\section{Non-profit Organisations Recovering and Distributing Surplus Food as Brokers of Unmet Needs}

We propose considering non-profit organisations active in the field of food recovery and food poverty from a social innovation perspective, assuming the following as a working definition: "social innovation is a distinctive and effective response to address unmet needs motivated by a social purpose which enhances social assets and capabilities" (Sinclair and Baglioni 2014: 471). We focus on non-profit organisations' capacity to create new relationships among social actors (private forprofit and private non-profit, as well as public actors) while helping to meet various unmet needs. Figure 1 summarises our model of thinking regarding non-profit organisations as agents of brokerage among various needs, which results in social innovation.

(1) First, they help to meet the nutritional needs of people in difficult economic circumstances (e.g. unemployed, asylum seekers, homeless, migrants, single parents, those with addictions, pensioners), in addition to providing other services such as the distribution of clothes or opportunities to socialise with other beneficiaries or volunteers;

(2) Second, non-profit organisations help private companies working in the food supply chain to manage their over-production and waste costs as well as developing their corporate social responsibility policy; 


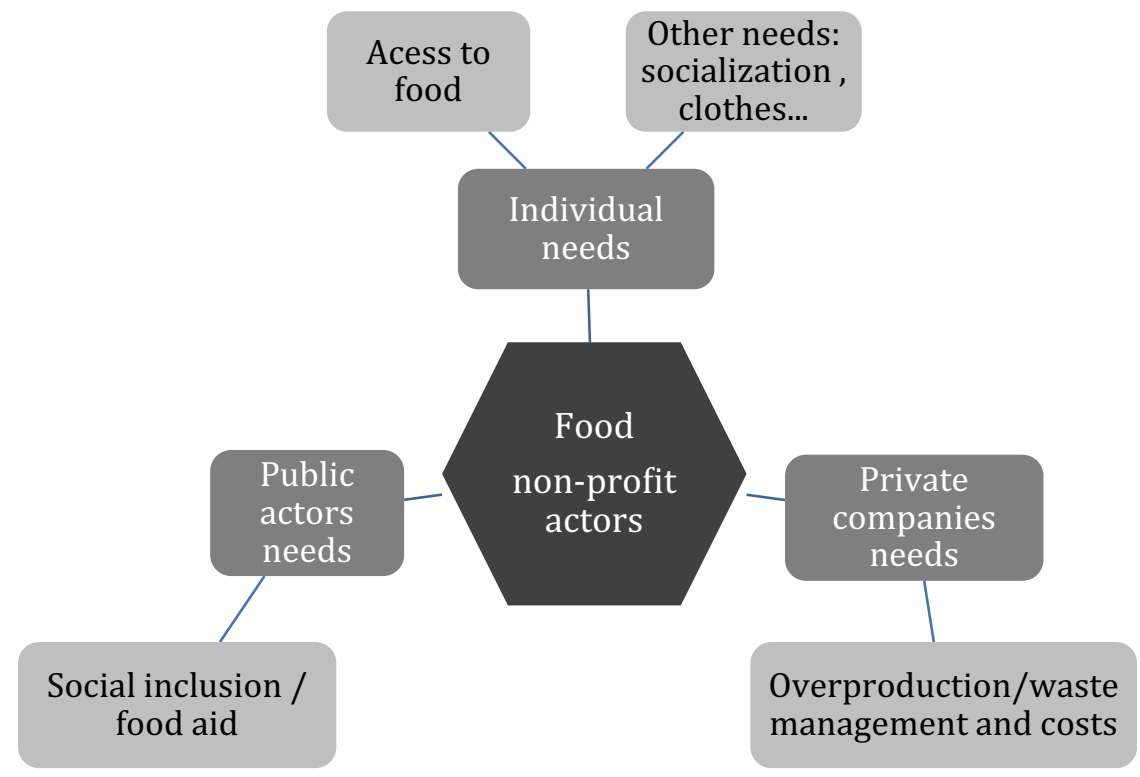

Fig. 1 Non-profit actors in the food recovery field as brokers connecting different actors' needs

(3) Third, food recovery non-profit organisations support public actors by managing food aid projects that would otherwise not be implemented by the welfare system, while inspiring policy innovation and raising public awareness.

Built upon such a model, we present our analysis following the three-fold differentiation of non-profit actors inferred from our fieldwork. We recognise logistical, front-line and hybrid organisations and show in the following sections how they relate to service users, private companies/donors and public actors (as summarised in Table 1).

Logistical organisations are those primarily devoted to collecting food from producers and retailers and delivering it to other organisations (front-line organisations), who subsequently provide such food to people in need. Hybrid organisations are those that fulfil both these functions.

\section{Relations with Service Users}

We begin our discussion and analysis of the German and Italian cases from the relationships that non-profit organisations establish with their clients or service users.

Not all the organisations involved in food recovery have a direct contact with beneficiaries. For instance, logistical organisations do not distribute food directly to the needy; rather, they work as intermediates between donor companies and front- 
Table 1 The three models of non-profit organisations working on food recovery

\begin{tabular}{|c|c|c|c|}
\hline & Front-line & Logistical & Hybrid \\
\hline $\begin{array}{l}\text { Relations with } \\
\text { beneficiaries }\end{array}$ & Direct & None & Direct \\
\hline $\begin{array}{l}\text { Relations with } \\
\text { donors and } \\
\text { sponsors }\end{array}$ & $\begin{array}{r}\text { Indirect for big donors, } \\
\text { direct for small ones }\end{array}$ & Direct & $\begin{array}{l}\text { Both direct and } \\
\text { indirect (through } \\
\text { logistic } \\
\text { organisations) }\end{array}$ \\
\hline $\begin{array}{l}\text { Relations with } \\
\text { policy- } \\
\text { makers }\end{array}$ & $\begin{array}{l}\text { Rare and only with local } \\
\text { ones }\end{array}$ & Rare & $\begin{array}{c}\text { Rare and generally } \\
\text { with local ones }\end{array}$ \\
\hline $\begin{array}{l}\text { Needs } \\
\quad \text { addressed }\end{array}$ & $\begin{array}{l}\text { People nutrition and other } \\
\text { basic needs (clothing, } \\
\text { socialisation needs) }\end{array}$ & $\begin{array}{l}\text { Food supply to local non-profit } \\
\text { front-line; food companies } \\
\text { food "waste" management }\end{array}$ & $\begin{array}{l}\text { People nutrition; } \\
\text { food companies } \\
\text { "waste" } \\
\text { management }\end{array}$ \\
\hline
\end{tabular}

line organisations. The latter have a direct relationship with their users, dealing with them in their everyday activities. Furthermore, several social organisations have also developed "hybrid" programmes in recent years, combining logistical activities and the partly or entirely autonomous management of the supply channels, involving direct contact with service users and innovative forms of food recovery and redistribution.

Soup kitchens and food pantries are the most common and traditional type of front-line organisations dealing with food poverty. They are grassroots and locally based organisations, heavily relying on volunteers (Gentilini 2013; Eisinger 2002; Mosley 2000). Soup kitchens and food pantries traditionally distribute food hampers or complete meals to those in need. As an important barrier, some authors recognise the fact that some of the food donated by these organisations do not always match clients' needs, for example those with particular ethnic backgrounds or specific dietary requirements (Verpy et al. 2003). Furthermore, there are doubts about the capacity of food pantries providing hampers in terms of satisfying users' daily nutritional requirements (Evans et al. 2008; Irwin et al. 2007).

In the case of "hybrid" models such as the so-called social restaurants, social coffee shops and social markets, users are regarded more as "active customers" than passive beneficiaries. Rather than distributing a pre-packed bag or a pre-determined dinner, these organisations allow customers to choose their products for a nominal price (Holweg and Lienbacher 2011; Popielarski and Cotugna 2010).

An example of a hybrid organisation is the German 'Tafel' (which in German means 'dining table'), founded in Berlin in 1993 based upon the model of American food banks. By 2014, the Bundesverband Deutsche Tafel (the German Federation of the Tafels) comprised 916 local organisations across the country, involving about 50,000 volunteers (some of whom are unemployed people involved in reintegration programmes). According to its annual report, the federation helps more than 1.5 million people in Germany (Bundesverband Deutsche Tafel 2014). Typical beneficiaries of this organisation include old-age pensioners, asylum seekers, recipients of social subsidies, single parents and other low-income categories that 
have kitchens facilities to prepare the products that they receive (von Normann 2009).

The Tafel has a federal structure, whereby local agencies work as logistical as well as front-line distribution points, while the head office in Berlin has mainly logistical, administrative and institutional functions (see Fig. 2). The federation connects and advises the local distribution points, seeks sponsors and major donors, manages major donations at a national level and leads lobbying and public relations. Each local Tafel differs in terms of its dimensions, activities and financial resources. More than 900 local Tafel run about 3000 distribution points at a national level. They work either as "Tafel-Läden"-namely as social shops or social supermarkets-or as points for the distribution of food packs or bags. Some of them also distribute food to other local organisations, running like small and local pure logistical organisations (von Normann 2009; Bundesverband Deutsche Tafel 2014).

Although the Tafel is a national federation with a unique identity, broad independence is guaranteed to local branches, whereby it does not have a unified and homogeneous structure but relevant differences exist between different regions. This is a peculiar characteristic of this German organisation and hence it is worth stressing that our field research focuses only on some local Tafel in BadenWürttemberg.

The federal structure of the Tafel and the variety of local distribution models is a unique case in the European context. Most of the other European food banks have a more linear logistical structure, whereby they have a national or regional headquarter, collect food from companies and redistribute it to other front-line

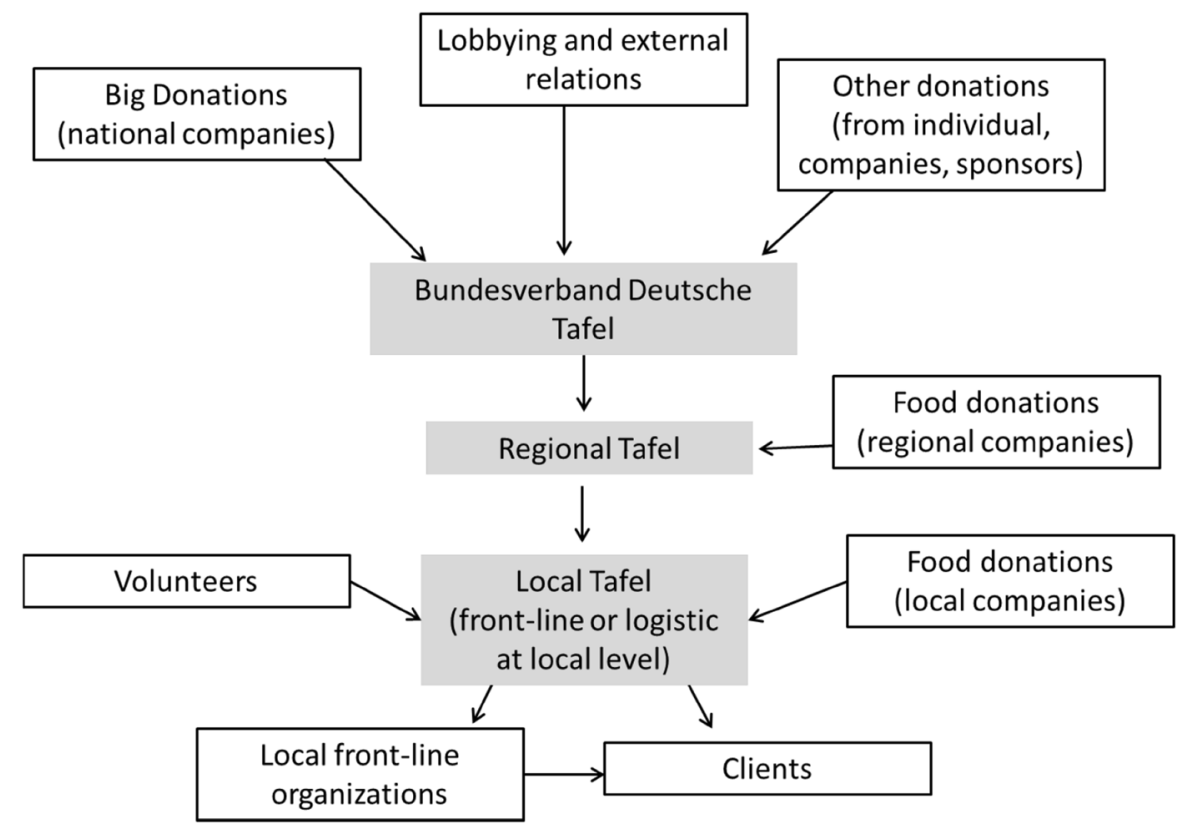

Fig. 2 A diagram illustrating the functioning of the Tafel at national, regional and local level 
organisations in charge of the distribution to the beneficiaries. These more traditional food banks are gathered in the European Federation of Food Banks (FEBA), which has 23 members (including the Italian foundation "Banco Alimentare") in 22 European countries. An interesting signal of its diversity is the fact that the Tafel is not a regular member of the FEBA, although it collaborates with it according to a partnership agreement.

Concerning the relation with users in hybrid organisations, the former are often regarded more as consumers and clients rather than mere beneficiaries. Particular care is devoted to preserving people's dignity. For instance, when we visited the back office of one of the Tafel's social markets, we saw volunteers carefully screening food prior to its display on the shelves, whereby only food in good shape and packaging was presented to clients to avoid any implication or suggestion of a 'wasted food' market. We also noticed an attention to dietary requirements, as well as making available a wide range of fresh and dry products, as far as the supply chain allows it.

Concerning the first need-food aid-there is no doubt that the non-profit organisations that we visited and whose staff we interviewed provide food to people who otherwise cannot afford the same variety and quality elsewhere. As such, these organisations are able to meet a basic human need not addressed by the provision of the general welfare state in either Germany or Italy. There are individuals and groups that fall within categories or cases for which the usual and standardised forms of social and income support do not provide any or sufficient coverage. They are at risk of destitution due to their economic, social or legal status, and for them a food recovery market or soup kitchen represents the only way to properly feed themselves and their families.

In all these organisations, the relationships with service users are always primarily aimed at meeting people's need to access food products. However, some organisations also try to pursue other activities related to the risk of social exclusion; for example, by allowing service users to socialise and meet other people. In the specific circumstances in which most of the service users find themselves, such as being immigrants without employment, asylum seekers or elderly people with no family connections, the possibility to meet other people and socialise with them is sometimes as valuable as receiving food.

Food recovery mini markets or shops run by non-profit entities can also provide opportunities for socialisation and leisure that most users would rarely find elsewhere. Particularly regarding the German Tafel, Lorenz not only notes that users take advantage of the very inexpensive food to relieve the burden on their household budget, but also the local shop provides "an opportunity for participating in a social setting, for not being alone, and for taking part in joint activities" (Lorenz 2012, p. 390).

Accordingly, during our observation at a social market in Germany, for example, we could see a social space and a café area where people can sit and discuss with others while drinking a tea or coffee. Moreover, we observed a group of old men of Middle East origin drinking mint tea while discussing, as would happen in any ordinary café. In this case, the social space of the food recovery organisation allows 
people to experience everyday leisure activities and socialisation, in a way normalising what could be perceived as a marginalised status.

Stigmatisation is indeed very strong in both Germany and Italy, according to our interviewees. We were told that food pantries and soup kitchens would have more beneficiaries if people felt less social pressure and stigmatisation. Beneficiaries often feel observed and judged by the neighbouring inhabitants of food recovery markets due to their status of deprivation, and thus they refrain from attending the premises as often as they would like or need.

Therefore, the presence of such a social space in these organisations is also a way to mitigate potential feelings of self-stigmatisation, as people perceive their daily or weekly visit to the food market as a social event rather than a mere means to assure themselves of essential food.

\section{Relation with Donors}

Relationships with donors are usually a prerogative of logistical organisations. The Tafel is the most important organisation dealing with the logistics of food donations at a national level in Germany, while in Italy the same function is performed by the Lombardy-based Fondazione Banco Alimentare (Food Bank Foundation) created in 1989. It coordinates a network of local food banks operating mainly at the regional level, collecting and redistributing food to front-line organisations in their regions (see Fig. 3). We interviewed the most important local bank in terms of scale, volume of food managed and number of volunteers, namely the "Associazione

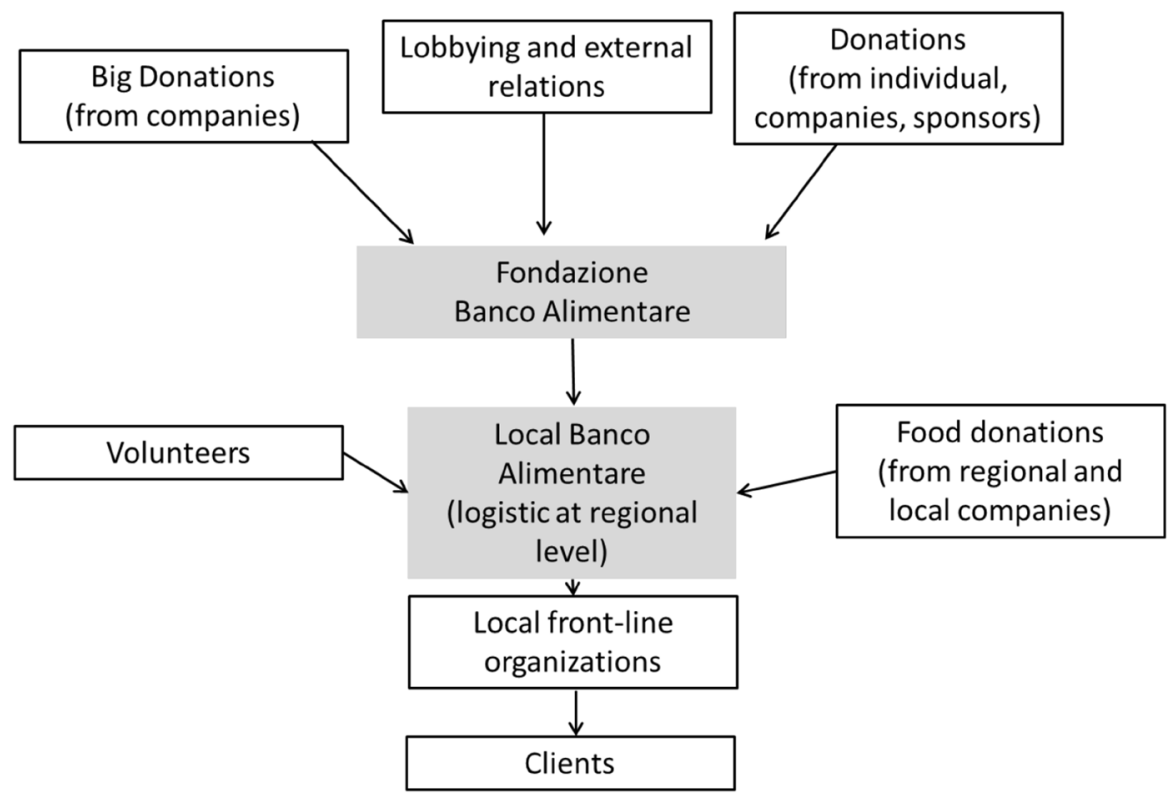

Fig. 3 A diagram illustrating the functioning of Fondazione Banco Alimentare and its regional branches 
Banco Alimentare della Lombardia" (ABAL), the Lombardy branch of the Foundation, based in Muggiò, near Milan.

Logistical organisations play a vital function in food recovery and food poverty practices. To the best of their capacities, they secure a supply of food of sufficient quality and quantity to meet the demand. The development and maintenance of such a supply operation is based upon two elements: logistical organisations' know-how and infrastructure as well as their capacity to establish trust-based relationships with donor companies.

To manage a large supply process, a few elements are needed: warehouses to stock donations, lorries and drivers for immediate collection and delivery-as fresh products can deteriorate quickly_, volunteers to fulfil administrative duties (according to our interviews, regulations and bureaucracy are very onerous) and the ability to build a solid network with local organisations receiving food. Indeed, logistical organisations not only have transport and stocking capacities, but they are also able to develop partnerships with donor companies, concerning both the donation of food and logistic partnerships.

For example, in Italy, the ABAL collaborates with logistical companies to share lorries and transport costs. Accordingly, lorries dispatched by a company to deliver its product — which might otherwise travel back empty — can be diverted to a nearby food donor to collect donated food and deliver it to the ABAL warehouse. Logistical organisations' know-how also includes the updated and in-depth knowledge of health and safety regulations related to food, as well as the capacity to adhere to the detailed fiscal and trade norms.

Private companies keen to donate surplus food try to minimise two main risks: having their reputation damaged as a consequence of a donation (e.g. if donated food is not appropriately treated and thus harms those who eat it) and having their production and market position jeopardised by their donation being sold or smuggled to the secondary markets.

Such concerns can only be overcome by developing a trusted relationship with the logistical non-profit organisation. In fact, logistical organisations can support companies to manage and recover the surplus food generated for a social aim.

Each actor across the supply chain generates surplus food due to different causes, such as exceeding the internal sell-by-date, forecasting or processing errors, packaging failures, inappropriate procedures for stacking and shelving, inefficient stock rotation, failed introductions of new products or failed promotions (Garrone et al. 2014a, b). In these cases, logistical organisations can secure the re-use of surplus food through its recovery and distribution to charities, thus helping companies to avoid having their products wasted or undersold on insidious secondary markets (Garrone et al. 2014a, b).

Sometimes front-line organisations can directly manage their relationships with donors, especially in the case of local donors (local supermarkets, bakeries or canteens); indeed, this happens in both the countries studied here. In Germany, several interviewees told us that trust between the local Tafel and suppliers is particularly the key when a change in the top management of local small supplier occurs (for example, a simple change of management at a supermarket), which can lead to the end of the donation. It is worth noting that in the case of local Tafel, such 
localised trust between companies and front-line organisations is maintained by the work of volunteers, who are the main drivers regularly visiting local suppliers. These drivers operate as front-line brokers for the organisations as well as their informants, providing information about the relationship with the donor as well as the quality and quantity of the donated food.

In Italy, front-line organisations generally have fewer direct relationships with donors and mainly rely on logistical organisations for their supply. However, the ABAL has recently developed a new model of "tutorship" to advise and support local front-line organisations. Within this new service, the ABAL not only supplies food to the local organisations, but also accompanies and supports them in the creation of local partnerships, facilitating new relationships with companies. Since front-line organisations - as described above_-generally have limited logistical and networking ability, they encounter many difficulties in developing partnership with donor companies. Therefore, the ABAL "tutorship" is very important: the ABAL takes charge of the verification process and all the administrative procedures, while the local organisation is responsible for the collection and redistribution of donated products. This helps small local organisations to develop new partnerships with companies, counting upon the trustworthiness of ABAL. In addition, the latter's intermediation is a guarantee for companies that have neither the ability nor the time to verify that each receiving organisation respects hygienic, administrative and social requirements. Moreover, these partnerships between local organisations and companies - particularly local retailers - allow the recovery of fresh products (fruit, vegetable, milk products and other foods with a short shelf life donated by points of sale), which need to be distributed and consumed within a short time.

\section{Relation with Policy-Makers}

Direct relationships between these non-profit actors and policy-makers are generally rare. Our interviews revealed that these organisations and public institutions collaborate mainly for information exchange or the implementation of specific local projects.

Logistical organisations are generally more capable than front-line organisations in terms of developing relationships with national or regional governments, as they are often considered by policy actors as being "the representatives" of the sector.

This is the case with Fondazione Banco Alimentare in Italy. Banco Alimentare takes part in working groups organised by public authorities to discuss reforms and the regulation of food recovery and donations, at both the regional and national level. In the Italian case, our interviewees confirmed that the Banco Alimentare collaborates with the Ministry of Agriculture, the Ministry of Welfare and the Health Ministry, as well as receives a relevant financial contribution from the regional government of Lombardy.

The German Tafel does not receive financial contributions from the public sector, although it is involved in some of the projects (mainly campaigns) promoted by national or regional authorities.

Front-line and hybrid local organisations can count upon local and limited networks and generally municipalities are the only public institutions with whom 
they collaborate. Due to their limited organisational capacity and main reliance on volunteers, authorities do not get them involved in working groups or large-scale projects. This is the case for both Italy and Germany, where local partnerships with municipalities primarily concern the donation of spaces to implement organisations' activities or collaborations with local social services. In some cases-for example, in Germany-Tafel have their offices or locations based in publicly-owned buildings, which are provided to them for free or at a nominal cost.

In Italy, several local front-line and hybrid organisations pointed out the existence of positive relationships with local authorities, although they assessed such relationships as episodic and unsystematic and they lamented the lack of proper food recovery policies.

The overall picture that emerged from speaking with non-profit actors about their connection with policy-makers and governmental authorities is one of a de facto devolved function. While feeding people in need should be a prior concern of modern welfare states and public intervention should elaborate systemic policymaking simultaneously addressing the intertwined issues of hunger, food waste and environmental protection, our research found a lack of commitment among public actors, counter-balanced by a deep commitment among civil society organisations and ordinary citizens. Public actors refrain from intervening aside from limited actions, thus leaving an open space for citizens' action to build and develop strategies and practices to tackle various social problems; accordingly, we regard such strategies and practices as being socially innovative. However, it is clear that this public disengagement from such a significant field raises serious issues about the quality and legitimacy of our democracies. ${ }^{5}$

\section{Concluding Remarks}

Food poverty - as well as food recovery as a way of tackling it-has become a salient issue in policy, academic and public debates over the last decade. The economic crisis, the reshuffle of the economy and labour markets on a global scale-together with mass migrations and mobility-have contributed to bringing the issue back among the public realm, whereas affluent societies like European ones had considered the issue solved forever.

In fact, traditional welfare state models and their anti-poverty policies have neglected such an issue, perceiving it as a residual problem among the wider spectrum of societal challenges. Governments and public actors have kept considering food poverty a problem to be solved by civil society based upon the classic model of civil societies' development in Western Europe, where organised acts of solidarity and compassion were promoted by religious bodies or social democratic movements.

Therefore, specifically public policies dealing with food poverty and food recovery remain rare and are only properly developed in a few selected countries. In

\footnotetext{
5 At the time of writing this paper, the Fund for European Aid to the Most Deprived (FEAD) was under discussion and an agreement on its content had not been reached. It has now been approved and it starts being implemented. Its effects in promoting a change on food recovery policies, though, will have to be monitored in the years to come.
} 
most cases, it is up to civil society organisations and private companies to develop solutions to meet various unmet needs.

Our exploratory study of non-profit organisations in two European regions (Lombardy in Italy, and Baden-Württemberg in Germany) has highlighted some of the specific functions played by non-profit organisations in this field. These organisations operate at the intersection between individual and collective actors. First, they operate at an individual level to address a specific basic need-access to food-together with other non-material needs, such as socialisation. Besides, they operate to meet such needs while preserving the dignity of service users, which is not always easy to achieve given the widespread stigmatisation and prejudice in wealthy societies concerning such practices and deprived people. Finally, non-profit organisations help meet private companies' needs, supporting the latter in both managing the surplus food produced and boosting their reputation thanks to the social activity.

Non-profit organisations and private companies donating food both operate in a context that does not facilitate their action or their collaboration. Health and safety regulations obstruct donations and particularly the risk of liability, according to which companies (or non-profit organisations) are responsible for their productsincluding those that they donate-and thus at risk of being sued. The fiscal benefits are small and very often it is more convenient for companies to send surplus food to waste rather than donating it.

In conclusion, in both Italy and Germany, there remains more to be done to enhance the recovery of surplus food and its redistribution to those in need. Indeed, at the time of this study, current forms of food poverty are mainly addressed through volunteers and the organisations for which they work. Nonetheless, such a situation provides evidence that social innovation is possible even with limited means and against an unfavourable political and legal context.

Acknowledgments The paper is based on research carried out in the framework of the project entitled: Foodsaving: at the crossroad of food recovery, funded by the Fondazione Cariplo and the Government of the Lombardy Region. Authors wish to acknowledge the valuable support received by their coinvestigators (Giorgio Fiorentini, Francesca Calò, and Elisa Ricciuti) throughout the research process. They are also grateful to two anonymous reviewers for their valuable 'objections and suggestions' on earlier versions of the paper.

Open Access This article is distributed under the terms of the Creative Commons Attribution 4.0 International License (http://creativecommons.org/licenses/by/4.0/), which permits unrestricted use, distribution, and reproduction in any medium, provided you give appropriate credit to the original author(s) and the source, provide a link to the Creative Commons license, and indicate if changes were made.

\section{References}

Azzurro, P. (2015). La donazione degli alimenti invenduti verso la semplificazione normativa. PINPAS, Piano Nazionale di Prevenzione degli Sprechi Alimentari Ministero dell'Ambiente, Dipartimento di Scienze e Tecnologie Agro-alimentari, Alma Mater Studiorum Università di Bologna.

BCFN. (2012). Food waste: Causes, impacts and proposal. Milan: Codice Edizioni. 
Bloom, J. (2010). American wasteland. How America throws away nearly half of its food (and what we can do about it). Cambridge, MA: Da Capo Press.

Bundesverband Deutsche Tafel E. V. (2014). Kein Grund zum Feiern?! 20 Jahre Tafeln in DeutschlandJahresbericht 2013.

Conceição, P., \& Mendoza, R. (2009). Anatomy of the global food crisis. Third World Quarterly, 30(6), 1159-1182.

Defourny, J., Hulgard, L., \& Pestoff, V. (2014). Social enterprise and the third sector. Changing European landscapes in a comparative perspective. London: Routledge.

Deloitte. (2014). Comparative Study on EU Member States' legislation and practices on food donation. Final report prepared by Bio By Deloitte for the European Economic and Social Committee. Brussels.

Denzin, N. K., \& Lincoln, Y. S. (Eds.). (2000). Introduction: The discipline and practice of qualitative research. Handbook of qualitative research (2nd ed., pp. 1-28). Thousand Oaks: Sage.

Department for Environment, Food and Rural Affairs (DEFRA). (2005). Securing the future: Delivering UK sustainable development strategy. London: DEFRA.

Dowler, E. (1998). Food poverty and food policy. IDS Bulletin, 29(1), 58-65.

Duffy, P. A., Hallmark, G. G., Molnar, J., Claxton, L., Bailey, C., \& Mikloucich, S. (2002). Food security of low-income single parents in East Alabama: Use of private and public programs in the age of Welfare Reform. Southern Rural Sociology, 18(1), 48-81.

Eisinger, P. (2002). Organizational capacity and organizational effectiveness among street-level food assistance programs. Nonprofit and Voluntary Sector Quarterly, 31, 115-130.

Eng, C. (2011). Watching our waste lines. Gastronomica, 11(3), 100-102.

Engler-Stringer, R., \& Berenbaum, S. (2007). Exploring food security with collective kitchens participants in three Canadian cities. Quality Health Research, 17(1), 75-84.

European Commission. (2010). Preparatory study on food waste across the EU 27. Brussels: European Communities.

European Commission. (2015). Flash Eurobarometer 425-September 2015, "Food waste and date marking", Brussels.

Evans, S. H., Clarke, P., \& Koprowski, C. (2008). Information design to promote better nutrition among pantry clients: Four methods of formative evaluation. Public Health Nutrition, 13(3), 430-437.

FAO. (2009). The State of Food Insecurity in the World. Rome: FAO.

FAO. (2011). Global food losses and food waste: Extent, causes and prevention. Rome: FAO.

Federal Ministry of Food, Agriculture and Consumer Protection [Bundesministerium für Ernährung, Landwirtschaft und Verbraucherschutz]. (2012). Leitfaden für die Weitergabe von Lebensmitteln an soziale Einrichtungen - Rechtliche Aspekte.

Ferrara, I., \& Missios, P. (2012). A cross-country study of household waste prevention and recycling: Assessing the effectiveness of policy instruments. Land Economics, 88(4), 710-744.

Finn, S. M. (2011). A public-private initiative to reduce food waste: A framework for local communities. Graduate Studies Journal of Organizational Dynamics, 1(1), 3.

Friel, S., \& Conlon, C. (2004). Policy response to food poverty in Ireland. Dublin: Combat Poverty Agency.

Garrone, P., Melacini, M., \& Perego, A. (2014a). Opening the black box of food waste reduction. Food Policy, 46, 129-139.

Garrone, P., Melacini, M., \& Perego, A. (2014b). Surplus food recovery and donation in Italy: The upstream process. British Food Journal, 116(9), 1460-1477.

Gentilini, U. (2013). Banking on food: the state of food banks in high-income countries, IDS Working paper, Volume 2013 Number 415.

Gregory, P. J., Ingram, J. S. I., \& Brklacich, M. (2005). Climate change and food security. Philosophical Transactions of the Royal Society, 360, 2139-2148.

Holweg, C., \& Lienbacher, E. (2011). Social marketing innovation: New thinking in retailing. Journal of Nonprofit \& Public Sector Marketing, 23(4), 307-326.

IFRC. (2013). Think differently, Humanitarian impacts of the economic crisis in Europe. 1260300 10/2013, Geneva.

Irwin, J., Ng, V., Rush, T., Nguyen, C., \& He, M. (2007). Can food banks sustain nutrient requirements? Canadian Journal of Public Health, 98(1), 17-20.

Jha, M. K. (2009). Food security in perspective: The significance of social action. Community Development Journal, 44(3), 351-366. 
Lang, T., \& Barling, D. (2012). Food security and food sustainability: reformulating the debate. The Geographical Journal, 178(4), 313-326.

Lorenz, S. (2012). Socio-ecological consequences of charitable food assistance in the affluent society: The German Tafel. International Journal of Sociology and Social policy, 32(7/8), 386-400.

Mosley, J. (2000). The food safety net after welfare reform: Use of private and public food assistance in the Kansas City Metropolitan Area. Social Service Review, 78(2), 267-283.

Parfitt, J., Barthel, M., \& Macnaughton, S. (2010). Food waste within food supply chains: quantification and potential for change to 2050. Philosofical Transactions of the Royal Society, B, 365(1554), 3065-3081.

Pestoff, V. (2009). A democratic architecture for the welfare state. London: Routledge.

Planchenstainer, F. (2012). "They collected what was left of the scraps": Food surplus as an opportunity and its legal incentives. The Trento Law and Technology Research Group Research Paper n. 13, University of Trento.

Popielarski, J. N., \& Cotugna, N. (2010). Fighting hunger through innovation: Evaluation of a food bank's social enterprise venture. Journal of Hunger \& Environmental Nutrition, 5(1), 56-69.

Riches, G. (2002). Food banks and food security: Welfare reform, human rights and social policy. Lessons from Canada? Social Policy and Administration, 36(6), 648-663.

Riches, G. (2011). Thinking and acting outside the charitable food box: hunger and the right to food in rich societies. Development in Practice, 21(4/5), 768-775.

Schneider, F. (2012). The evolution of food donation with respect to waste prevention. Waste Management, 33(3), 755-763.

Schneider, F., \& Lebersorger, S. (2012). The challenges of food wastage to European Society. 15th European Roundtable on Sustainable Consumption and Production (15th ERSCP) 2012.

Segré, A. (2014). PINPAS, Piano Nazionale di Prevenzione degli Sprechi Alimentari Le azioni prioritarie per la lotta allo spreco - 5 giugno 2014.

Selke, S., Ed. (2009). Tafeln in Deutschland. Aspekte einer sozialen Bewegung zwischen Nahrungsmittelumverteilung und Armutsintervention, VS Verlag für Sozialwissenschaften, Wiesbaden.

Sinclair, S., \& Baglioni, S. (2014). Social innovation and social policy: Promises and risks. Social Policy and Society, 13(3), 469-476.

Verpy, H., Smith, C., \& Reicks, M. (2003). Attitudes and behaviors of food donors and perceived needs and wants of food shelf clients. Journal of Nutrition Education and Behavior, 35(1), 6-15.

von Normann, K. (2009). Ernährungsarmut und „Tafelarbeit“ in Deutschland. Distributionspolitische Hintergründe und nonprofit-basierte Lösungsstrategien. In: S. Selke, (Ed.) Tafeln in Deutschland. Aspekte einer sozialen Bewegung zwischen Nahrungsmittelumverteilung und Armutsintervention, VS Verlag für Sozialwissenschaften Wiesbaden.

Yin, R. (1989). Case study research. Thousand Oaks: Sage.

Zimmer, A. \& Brauer, S. (2015). The Development of Social Enterprises in Germany, National Report Delivered for the EU FP7 Project EFESEIIS, available at: http://www.fp7-efeseiis.eu.

Zimmer, A., \& Evers, A. (Eds.). (2010). Third sector organizations facing turbulent environments. Frankfurt: Nomos. 